\title{
Vistafin as an Independent Predictor for Declined Numerous of Non-Classical Endothelial Progenitor Cells in Patients with Type 2 Diabetes Mellitus
}

\author{
Alexander E. Berezin* \\ Professor, MD, PhD, Internal Medicine Department, State Medical University, 26, Mayakovsky av., \\ Zaporozhye, Ukraine \\ dr_berezin@mail.ru \\ Tatyana A Samura
}

Associate Professor, MD, Clinical Pharmacology Department, State Medical University, Zaporozhye, Ukraine

\section{Alexander A. Kremzer}

Associate Professor, MD, Clinical Pharmacology Department, State Medical University, Zaporozhye, Ukraine

\section{Tatyana A Berezina}

MD, Private center "Vita-Center", Zaporozhye, Ukraine

Yulia V. Martovitskaya

MD, Immunology Department, Clinical Laboratory “Dia-Service”, Zaporozhye, Ukraine

\section{Elena A Gromenko}

MD, Pathology Bureau, Zaporozhye, Ukraine

\begin{abstract}
Background: The decreased number and impaired functions of endothelial progenitor cells (EPCs) may associate with cardiovascular disease including atherosclerosis. The role of vistafin in regulation of angiogenic EPC subset maturation in T2DM patients without known atherosclerosis is still not fully understood The aim of the study: to investigate an association of serum vistafin level and number of circulating EPCs in T2DM patients beyond known CV disease.

Methods: This case-control observational investigation was retrospectively evolved 54 subjects with T2DM and 35 healthy volunteers. The criteria for exclusion were as follows: typical anginal symptoms, evidences of preexisting coronary artery disease, i.e. myocardial infarction / acute coronary syndrome, angiographic evidence of asymptomatic coronary atherosclerosis obtained by multi spiral contrast-enhanced tomography angiography provided prior study entry, heart failure, declined glomerular filtration rate $<60 \mathrm{~mL} / \mathrm{min} / 1.73 \mathrm{~m}^{2}$, candidates for insulin therapy. The flow cytometry was used for predictably distinguishing cell subsets, which depend on expression of CD45, CD34, CD14, Tie-2, and VEGFR2. Biomarkers were measured at baseline of the study.
\end{abstract}

Results: All T2DM patients were divided depending median of vistafin level $(5.88 \mathrm{ng} / \mathrm{mL})$ in to two cohorts with low vistafin level $(<5.88 \mathrm{ng} / \mathrm{mL} ; n=29)$ and high vistafin level $(\geq 5.88 \mathrm{ng} / \mathrm{mL} ; n=25)$ respectively. Multivariate regression analysis we found that serum vistafin level associated significantly with BMI, age, hs-CRP level,

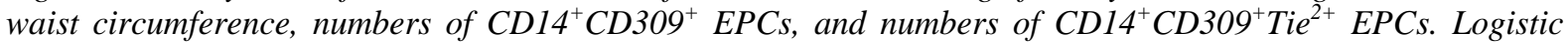
regression analysis has shown that visfatin, hs-CRP, age and BMI were the best variables in the prediction of EPC number labeled as $C D 14^{+} C D 309^{+}$and $C D 14^{+} C D 309^{+}$Tie ${ }^{2+}$ cells. After adjustment of the model to age and $B M I$ elevated visfatin level remained the best predictor for both $C D 14^{+} \mathrm{CD} 309^{+}$and $C D 14^{+} \mathrm{CD} 309^{+} \mathrm{Tie}^{2+} \mathrm{EPCS}$ (OR 0.92, 95\% CI: 0.88-0.95; $P=0.001$ and OR 0.90, 95\% CI: 0.87-0.96; $P=0.001$ respectively).

In conclusion, we found that elevated level of vistafin was an independent predictor for declined numerous of

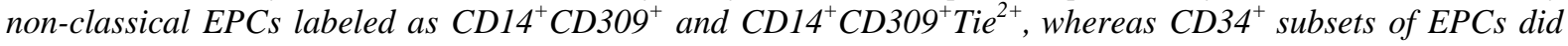
not associate with vistafin level in T2DM individuals.

Keywords: Diabetes mellitus; vistafin; endothelial-derived progenitor cells; cardiovascular risk factors. 


\section{INTRODUCTION}

The prevalence of type 2 diabetes mellitus (T2DM) has increased over recent decades, reaching worldwide epidemic [1]. T2DM exhibits substantial impact on global health and requires increased expenditures of economic resources and medical care, particularly when the disease is associated with microvascular and macrovascular complications [2]. Recent studies have revealed that increased cardiovascular (CV) risk in T2DM is linked to impaired endothelial function, which accompanies to insulin resistance, inflammatory activation, dyslipidemia, glucose and lipid cytotoxicity even beyond asymptomatic atherosclerosis and known CV disease [3-5]. Moreover, vascular complications are leading causes of $\mathrm{CV}$ morbidity and mortality in diabetes [5]. However, the metabolic crosstalk between endothelium integrity, vascular function and the endothelial repair systems is largely unknown and innate molecular mechanisms regarding cooperation of above-mentioned factors remain incompletely understood [6].

Visceral adipose tissue (VAT) communicates with other organs by the synthesis and release of wide spectrum of adipocytokines that have a critical role in inflammation, insulin resistance, obesity, T2DM and CV disease [7, 8]. Visfatin (also known as nicotinamide phosphorybosil transferase) is an adipocytokine, which widely expressed in liver, skeletal muscles, bone marrow and predominantly secreted by white VAT [9]. Recently, elevated level of vistafin was found in overweight/obesity, T2DM, metabolic syndrome and CV disease [10, 11]. Circulating level of vistafin has revealed closely relation rather VAT mass and low-grade systemic inflammation then insulin resistance [12, 13]. It has been reported that vistafin might mimic the effects of insulin, mediates cell growth and differentiation, and exhibit a vascular protective capacities [14-16]. Indeed, visfatin is thought to regulate the process of differentiation bone marrow mononuclear and endothelial progenitor cells and thereby it contributes in endothelium reparation and tissue protection [17].

Endothelial progenitor cells (EPCs) is a heterogenic population of mononuclear cells expressing endothelial and progenitor markers i.e. CD34+ antigen and VEGFR-2+ vascular growth ligands (Vascular Endothelial Growth Factor Rreceptor-2), CD133+, as well as CD14+, and Tie2+ (tyrosine kinase ligand) [18]. EPCs contribute in tissue repair, angiogenesis, and revascularization [19]. EPCs are mobilized from bone marrow and probably from peripheral tissues upon injury in result in growth factors and inflammatory cytokines [20]. Decreased numerous of circulating EPCs was found a marker of impaired endothelial function and early atherosclerosis [21]. Therefore, increased production of reactive oxygen species, insulin resistance, reduced NO bioavailability have been identified as mediators of tissue injury leading to lowered EPC functionality and reduced angiogenic capacity in vivo [22-24]. Although decreased number and impaired functions of EPCs may associate with CV disease including atherosclerosis, the role of vistafin in regulation of angiogenic EPC subset maturation in T2DM patients without known atherosclerosis is still not fully understood. The aim of the study: to investigate an association of serum vistafin level and number of circulating EPCs in T2DM patients beyond known CV disease.

\section{MethodS}

\subsection{Study Population}

This case-control investigation was retrospectively evolved 54 subjects with T2DM and 35 healthy volunteers. The criteria for exclusion were as follows: [a] typical anginal symptoms, [b] evidences of preexisting coronary artery disease, i.e. myocardial infarction / acute coronary syndrome, [c] angiographic evidence of asymptomatic coronary atherosclerosis obtained by multi spiral contrastenhanced tomography angiography provided prior study entry, [d] heart failure, [e] declined glomerular filtration rate $<60 \mathrm{~mL} / \mathrm{min} / 1.73 \mathrm{~m}^{2}$, [f] candidates for insulin therapy. All the patients have given their informed written consent for participation in the study. The study was approved by the local ethics committee of State Medical University, Zaporozhye, Ukraine. The study was performed in conformity with the Declaration of Helsinki.

T2DM was diagnosed with revised criteria provided by American Diabetes Association when source documents were reviewed [25]. When one or more of the following components were found (glycated hemoglobin $[\mathrm{HbA} 1 \mathrm{c}] \geq 6.5 \%$; fasting plasma glucose $\geq 7 \mathrm{mmol} / \mathrm{L} ; 2$-h plasma glucose $\geq 11.1 \mathrm{mmol} / \mathrm{L}$ during an oral glucose tolerance test; a random plasma glucose $\geq 11.1 \mathrm{mmol} / \mathrm{L}$; exposure of insulin or oral antidiabetic drugs; a previous diagnosis of T2DM) T2DM was determined.

\subsection{Smoking Status}

Current smoking was defined as consumption of one cigarette daily for three months. 


\subsection{Anthropometric Measurements}

Anthropometric measurements (body mass, waist and hip circumference) were made using standard procedures at baseline of the study.

\subsection{Image of Coronary Arteries' Analysis}

All scans of coronary arteries were interpreted by highly trained radiologists and one of subinvestigator independently each other before study entry. The identification of plaque and stenosis, as well as the amount of plaques per segment, was determined according conventional recommendation [26]. Plaques were recognized as abnormal structures in the artery wall that were within $1 \mathrm{~mm}^{2}$ of the vessel lumen. Asymptomatic CAD was defined as the presence of any types of plaque (calcified, noncalcified, and mixed) in coronary arteries.

\subsection{Cardiovascular Risk Calculation}

A 10-year cardiovascular risk for study patients was calculated using the Framingham General Cardiovascular Risk Score (2008) by on-line calculator and interpreted using contemporary approaches [27].

\subsection{Calculation of Glomerular Filtration Rate}

Glomerular filtration rate (GFR) was calculated with CKD-EPI formula [28].

\subsection{Blood Sampling}

To determine circulating biomarkers, blood samples were collected at baseline in the morning (at 7-8 a.m.) into cooled silicone test tubes wherein $2 \mathrm{~mL}$ of $5 \%$ Trilon B solution were added. Then they were centrifuged upon permanent cooling at $6,000 \mathrm{rpm}$ for 3 minutes. Plasma was collected and refrigerated immediately to be stored at a temperature $-70^{\circ} \mathrm{C}$.

\subsection{Measurement of Circulating Biomarkers}

Serum high-sensitive C-reactive protein (hs-CRP), adiponectin and vistafin were measured by highsensitive enzyme-linked immunosorbent assays using commercial available kits (R\&D Systems $\mathrm{GmbH}$, Wiesbaden-Nordenstadt, Germany) according to the manufacturers' recommendations. The inter-assay coefficients of variation were as follows: hs-CRP: $4 \%$, adiponectin: 5\%, vistafin: $4.2 \%$.

Fasting insulin level was measured by a double-antibody sandwich immunoassay (Elecsys 1010 analyzer, F. Hoffmann-La Roche Diagnostics, Mannheim, Germany). The intra-assay and inter-assay coefficients of variation were $<5 \%$. The lower detection limit of insulin level was $1.39 \mathrm{pmol} / \mathrm{L}$.

Concentrations of total cholesterol (TC), cholesterol of high-density lipoproteins (LDL-C), and cholesterol of high-density lipoproteins (HDL-C) were measured by enzymatic colorimetric method according standardized methodology on Beckman Synchron LX20 chemistry analyzer.

Direct Enzymatic HbA1c Assay was used for glycated hemoglobin A1c (HbA1c) measurements on Beckman Synchron LX20 chemistry analyzer.

\subsection{Insulin Resistance Determination}

Insulin resistance was assessed by the homeostasis model assessment for insulin resistance (HOMAIR) [29] using the following formula:

HOMA-IR $(\mathrm{mmol} / \mathrm{L} \times \mu \mathrm{U} / \mathrm{mL})=$ fasting glucose $(\mathrm{mmol} / \mathrm{L}) \times$ fasting insulin $(\mu \mathrm{U} / \mathrm{mL}) / 22.5$

IR was arbitrarily defined as a HOMA-IR value above the 75th percentile of normal glucose tolerance equal $2.45 \mathrm{mmol} / \mathrm{L} \times \mu \mathrm{U} / \mathrm{mL}$.

\subsection{Blood Sampling for Measurement of Circulating Endothelial Progenitor Cells and Mononuclear Progenitor Cells}

Blood samples were received from peripheral vein in blood collection tubes. Each sample contains 75 $\mu \mathrm{L}$ into $1 \mathrm{~mL}$ PBS containing $5 \mu \mathrm{M}$ EDTA (10 $\mu \mathrm{L}$ of $0.5 \mathrm{M}$ stock). To prevent clotting samples were mixed immediately. Peripheral blood mononuclear cells were removed using density gradient centrifugation with Ficoll-Paque (Miltenyi Biotec Inc., Germany). After layer $35 \mathrm{~mL}$ of diluted cell suspension over $15 \mathrm{~mL}$ of Ficoll-Paque in a $50 \mathrm{~mL}$ conical tub all blood samples with anticoagulants 
(EDTA) have centrifuged at $400 \times \mathrm{g}$ for $30-40$ minutes at $20^{\circ} \mathrm{C}$ in a swinging-bucket rotor without brake. The upper layer leaving the mononuclear cell layer was aspirated to prevent a contamination of samples before measurement of real EPCs.

\subsection{Assay of Circulating Endothelial Progenitor Cell and Mononuclear Progenitor Cell Subsets}

The flow cytometric technique (FCT) was used for predictably distinguishing circulating cell subsets, which depend on expression of CD45, CD34, CD14, Tie-2, and CD309 (VEGFR2), using HighDefinition Fluorescence Activated Cell Sorter (HD-FACS) methodology [30]. Accordingly, the cells were labeled on the basis of their forward scatter characteristic (FSC) and side scatter characteristic (SSC) profiles, and standardize and calibrate instruments, fluorescence and light scatter resolution, and sensitivity were determined accordingly standard protocol.

The cells were directly stained and analyzed for phenotypic expression of surface proteins using antihuman monoclonal antibodies, including anti-CD45 FITS (BD Biosciences, San Jose, CA, USA), anti-CD34 FITS (BD Biosciences), anti-VEGFR-2 known as anti-CD309 (BD Biosciences), anti-Tie2 (BD Biosciences) and anti-CD14 (BD Biosciences). The fluorescence minus one technique was used to provide negative controls and establish positive stain boundaries. After lysis of erythrocytes with UTILIZE wash solution, the samples were centrifuged at $200 \times \mathrm{g}$ for $15 \mathrm{~min}$. Then the samples were washed twice with PBS and fixed immediately. Double- or triple-positive events were determined using Boolean principles ("and", "not", "or", etc.).

\subsection{Determination of Circulating Endothelial Progenitor Cells}

Circulating EPCs were defined as CD34/ CD309 (VEGFR2) positive cells with lack of CD45 expression. From each tube 500,000 events were analyzed. For CD14+ populations, co-expression with Tie-2- and/or VEGFR-2- was determined using quadrant analysis. Standardized cell counts were presented as a percentage of the total of the white blood cells count, identified as the total number of all CD45+ cells. The FITC-labeled isotype control was analyzed with the same gate and window settings. The Fluorescence Minus One Control (FMO control) was used to properly interpret flow cytometry data. Figure 1 represents a sample of FACS results for CD45-/CD34+, CD309+/antiTie2-, CD14+/CD309+, CD14+/antiTie2- EPCs. FMO controls for CD14+/CD309+ is reported Figure 2.

Pro-angiogenic phenotype for EPCs was determined as $\mathrm{CD} 14^{+} \mathrm{CD} 309^{+}$(VEGFR2) Tie- $2^{+}$antigen presentation. The reproducibility of EPC measurements using the standard protocol was $3.5 \%$.
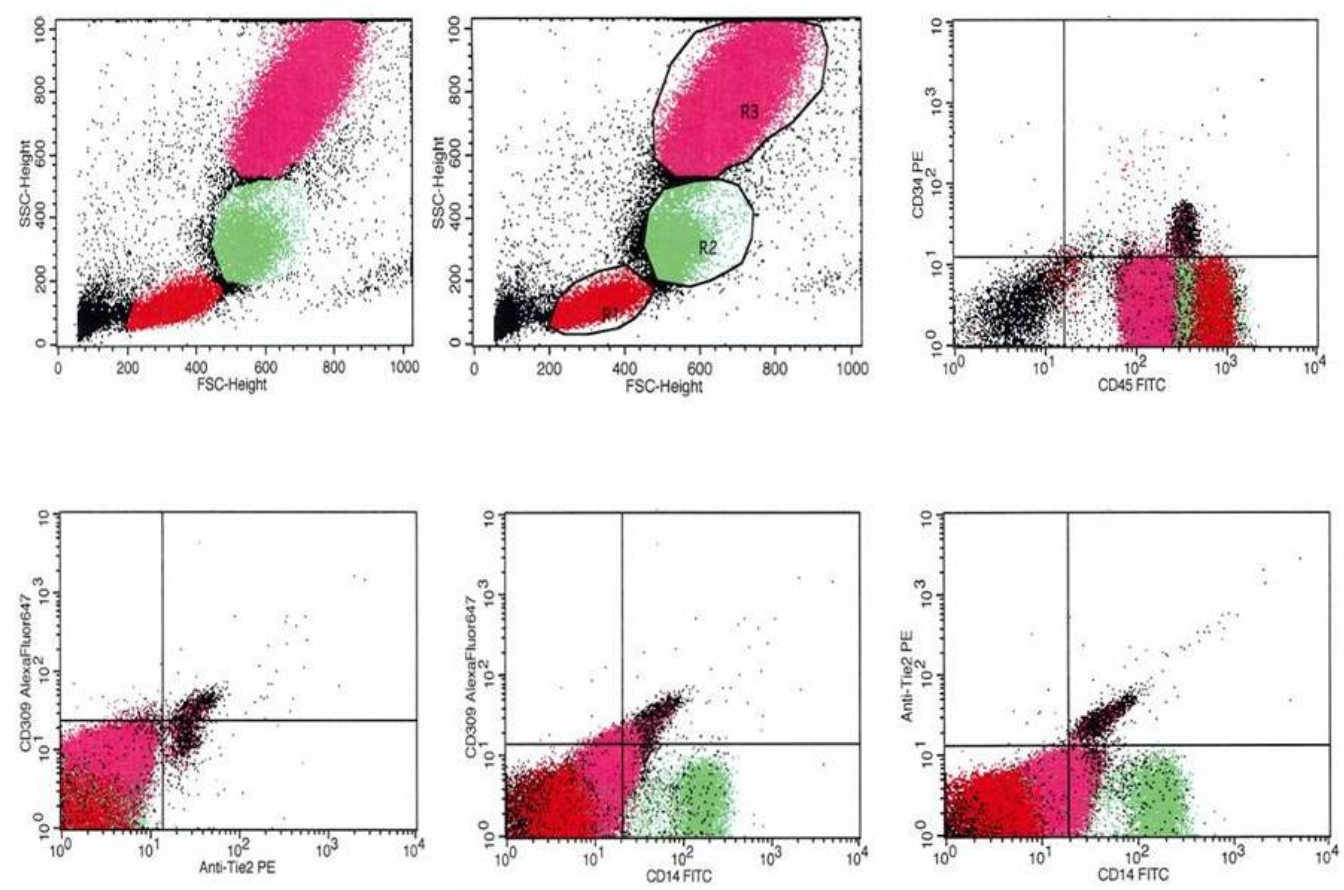

Figure1. The FACS Plots Present Results for CD45-/CD34+, CD309+/Antitie2-, CD14+/CD309+, CD14+/Antitie2- EPC Measurements 


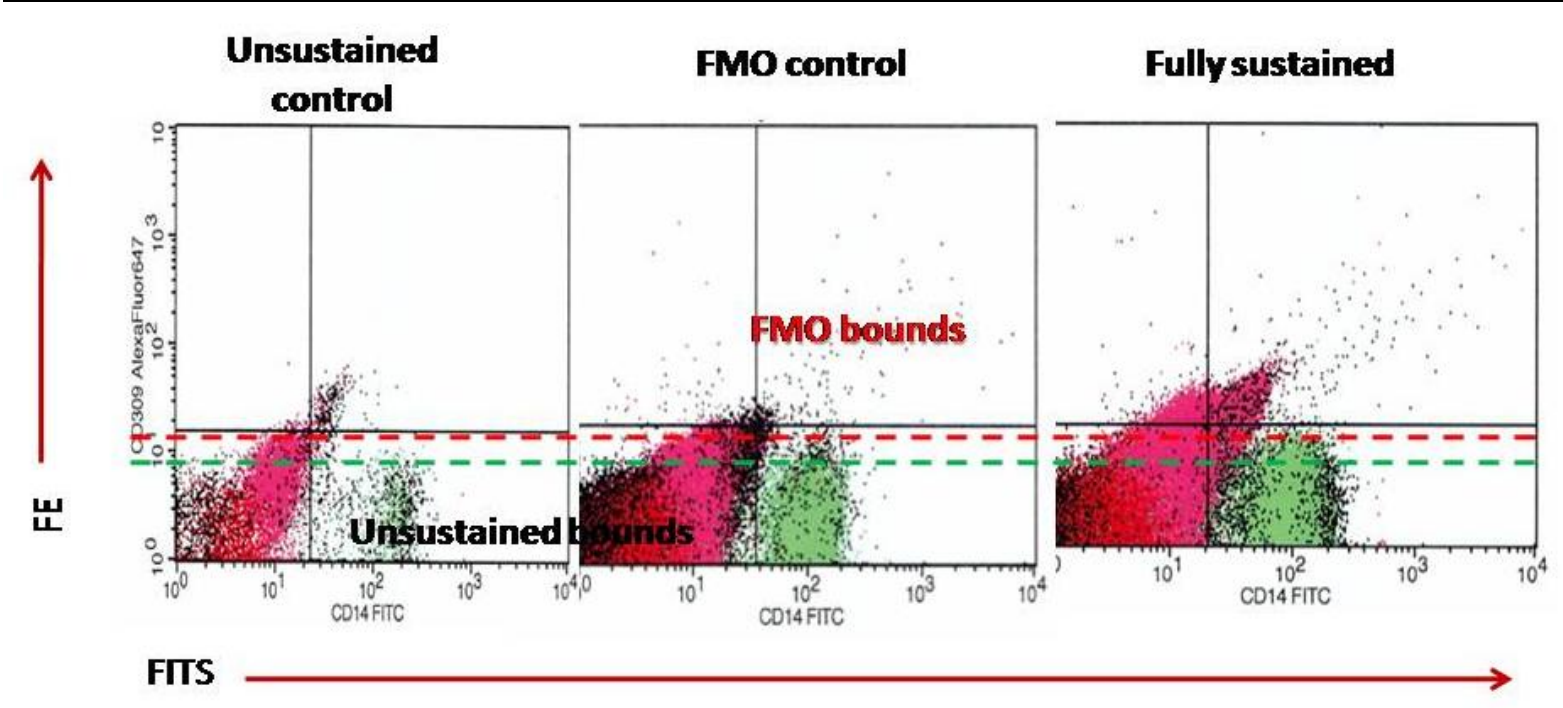

Figure2. FMO Controls for CD14+/CD309+ Measurement

\section{Statistical Analysis}

Statistical analysis of the results obtained was performed in SPSS system for Windows, Version 22 (SPSS Inc, Chicago, IL, USA). The data were presented as mean (M) and standard deviation ( \pm SD) or 95\% confidence interval (CI); as well as median (Me) and 25\%-75\% interquartile range (IQR). To compare the main parameters of patient cohorts, two-tailed Student t-test or Mann-Whitney U-test were used. To compare categorical variables between groups, Chi2 test $(\chi 2)$ and Fisher F exact test were used. The association between circulating visfatin and age, BMI, waist circumference, metabolic parameters, adiponectin, hs-CRP was done with univariate and multivariate regression analysis. $\beta$ coefficient and 95\% CI were calculated for each variable. Goodness of fit for obtained regression models was assessed with the determination coefficient $\mathrm{R}^{2}$. Predictors of depleted EPCs in patients were examined in multivariate regression analysis. A two-tailed probability value of $<0.05$ was considered as significant.

\section{Results}

General characteristic of patients participating in the study was reported in Table 1 . The mean age for patients with T2DM and healthy volunteers was 48.50 years and 46.12 years $(\mathrm{P}=0.68)$. Therefore $63.0 \%$ of $\mathrm{T} 2 \mathrm{DM}$ patients and $65.7 \%$ of healthy volunteers were men $(\mathrm{P}=0.86)$. There was a significant difference between healthy volunteers and entire cohort of T2DM patients in BMI, waist circumference, $\mathrm{CV}$ risk factors (hypertension, dyslipidemia, adherence to smoking), Framingham risk score, HOMA-IR, and lipid abnormalities. There were higher levels of HbA1c, fasting blood glucose, insulin, hs-CRP, TG, and vistafin in T2DM patient compared with healthy volunteers. Contrary, adiponectin level has defined lower in T2DM than in healthy volunteers. There was no significant difference in number of CD34+ subset cells (CD45+CD34+ and CD45-CD34+) between T2DM patients and healthy volunteers. However, decreased numerous of non-classical EPCs labeled as CD14+ subsets ( CD14+CD309+ and CD14+CD309+Tie2+) were found in T2DM compared with healthy volunteers $(\mathrm{P}=0.001$ for all cases).

Table1. General characteristic of patients participating in the study

\begin{tabular}{|l|c|c|c|}
\hline & $\begin{array}{c}\text { Healthy volunteers } \\
(\mathrm{n}=35)\end{array}$ & $\begin{array}{c}\text { Entire cohort of T2DM patients } \\
(\mathrm{n}=54)\end{array}$ & $\begin{array}{c}\mathrm{P} \\
\text { value }\end{array}$ \\
\hline Age, years & $46.12 \pm 4.22$ & $48.50 \pm 6.60$ & 0.68 \\
\hline Males, $\mathrm{n}(\%)$ & $23(65.7 \%)$ & $34(63.0 \%)$ & 0.86 \\
\hline BMI, $\mathrm{kg} / \mathrm{m}^{2}$ & $21.5(16.1-23.5)$ & $28.5(16.8-32.1)$ & 0.001 \\
\hline Waist circumference, sm & $78(63-89)$ & $98(89-110)$ & 0.001 \\
\hline Hip circumference $(\mathrm{cm})$ & $87(83-91)$ & $106(102-113)$ & 0.001 \\
\hline Hypertension, $\mathrm{n}(\%)$ & - & $36(66.7 \%)$ & 0.001 \\
\hline Dyslipidemia, $\mathrm{n}(\%)$ & - & $33(61.1 \%)$ & 0.001 \\
\hline Adherence to smoking, $\mathrm{n}(\%)$ & $6(17.1 \%)$ & $15(27.7 \%)$ & 0.001 \\
\hline
\end{tabular}


Alexander E. Berezin et al.

\begin{tabular}{|c|c|c|c|}
\hline Framingham risk score & $2.55 \pm 1.05$ & $8.18 \pm 2.32$ & 0.001 \\
\hline Systolic BP, mm Hg & $122 \pm 5$ & $136 \pm 5$ & 0.001 \\
\hline Diastolic BP, mm Hg & $72 \pm 4$ & $86 \pm 4$ & 0.001 \\
\hline Heart rate, beats per $1 \mathrm{~min}$. & $66 \pm 6$ & $72 \pm 5$ & 0.01 \\
\hline GFR, $\mathrm{mL} / \mathrm{min} / 1.73 \mathrm{~m}^{2}$ & $102.1(91.4-113.2)$ & $93.8(80.4-106.8)$ & 0.12 \\
\hline HbA1c, \% & $4.75(4.36-5.12)$ & $7.3(4.3-9.1)$ & 0.001 \\
\hline Fasting blood glucose, $\mathrm{mmol} / \mathrm{L}$ & $4.52(4.43-4.76)$ & $5.54(4.49-9.0)$ & 0.01 \\
\hline Insulin, $\mu \mathrm{U} / \mathrm{mL}$ & $4.98(1.5-14.1)$ & $15.6(12.9-16.8)$ & 0.001 \\
\hline HOMA-IR, $\mathrm{mmol} / \mathrm{L} \times \mu \mathrm{U} / \mathrm{mL}$ & $1.01(0.91-1.07)$ & $3.86(3.41-4.10)$ & 0.001 \\
\hline Creatinine, $\mu \mathrm{mol} / \mathrm{L}$ & $62.1(55.7-82.4)$ & $71.2(59.9-87.2)$ & 0.24 \\
\hline Total cholesterol, $\mathrm{mmol} / \mathrm{L}$ & $4.76(4.21-5.05)$ & $5.4(4.8-5.8)$ & 0.001 \\
\hline $\mathrm{LDL}-\mathrm{C}, \mathrm{mmol} / \mathrm{L}$ & $3.10(2.78-3.21)$ & $3.80(3.20-4.20)$ & 0.001 \\
\hline $\mathrm{HDL}-\mathrm{C}, \mathrm{mmol} / \mathrm{L}$ & $1.13(1.05-1.17)$ & $0.94(0.88-1.04)$ & 0.001 \\
\hline $\mathrm{TG}, \mathrm{mmol} / \mathrm{L}$ & $1.18(1.07-1.30)$ & $1.45(1.42-1.51)$ & 0.001 \\
\hline hs-CRP, mg / L & $4.11(0.97-5.03)$ & $8.10(4.80-9.54)$ & 0.001 \\
\hline Adiponectin, mg / L & $13.65(10.12-24.93)$ & $6.17(3.44-10.15)$ & 0.001 \\
\hline Vistafin, $\mathrm{ng} / \mathrm{mL}$ & $3.67(1.85-4.50)$ & $5.88(3.15-8.15)$ & 0.001 \\
\hline $\mathrm{CD} 45^{+} \mathrm{CD} 34^{+}$, cells $\times 10^{3} / \mu \mathrm{L}$ & $0.114(0.095-0.120)$ & $0.112(0.090-0.121)$ & 0.76 \\
\hline $\mathrm{CD}^{2} 5^{-} \mathrm{CD} 34^{+}$, cells $\times 10^{-1} / \mu \mathrm{L}$ & $0.06(0.05-0.07)$ & $0.057(0.053-0.067)$ & 0.86 \\
\hline $\mathrm{CD} 14^{+} \mathrm{CD} 309^{+}$, cells $\times 10^{-1} / \mu \mathrm{L}$ & $4.26(3.70-5.74)$ & $2.96(2.25-4.21)$ & 0.001 \\
\hline $\begin{array}{l}\mathrm{CD} 14^{+} \mathrm{CD} 309^{+} \mathrm{Tie}^{2+} \text {, cells } \\
\times 10^{-1} / \mu \mathrm{L}\end{array}$ & $0.465(0.253-0.710)$ & $0.270(0.241-0.411)$ & 0.001 \\
\hline
\end{tabular}

Note. Data are presented as mean and \pm SE or 95\% CI; median and 25-75\% IQR. Categorical variables are expressed as numerous ( $n$ ) and percentages (\%). P-value is a comparison of mean or median variables between both cohorts (ANOVA test).

Abbreviations. CI - confidence interval; IQR - inter quartile range; BMI - Body mass index, T2DM - type two diabetes mellitus, TG-triglycerides, BP - blood pressure, BMI - Body mass index, GFR - glomerular filtration rate, HDL-C - high-density lipoprotein cholesterol, LDL-C - Low-density lipoprotein cholesterol, hs-CRP-high sensitive $C$ reactive protein.

Patients with T2DM were treated with life-style modification, diet and orally taken antidiabetic drugs except sulfonylurea derivates and glitazones. Metformin in monotherapy or in combination with dipeptidyl peptidase-4 inhibitors or glucagon-like peptide-1 receptor agonists was given in individually optimized daily doses to be achieving full or partly full control for T2DM. Therefore, insulin was not used in T2DM patients.

All T2DM patients were divided depending median of vistafin level $(5.88 \mathrm{ng} / \mathrm{mL})$ in to two cohorts with low vistafin level ( $<5.88 \mathrm{ng} / \mathrm{mL} ; \mathrm{n}=29)$ and high vistafin level $(\geq 5.88 \mathrm{ng} / \mathrm{mL} ; \mathrm{n}=25)$ respectively. Figure 3 is reported the circulating vistafin level in both T2DM cohorts in comparison with healthy volunteers.

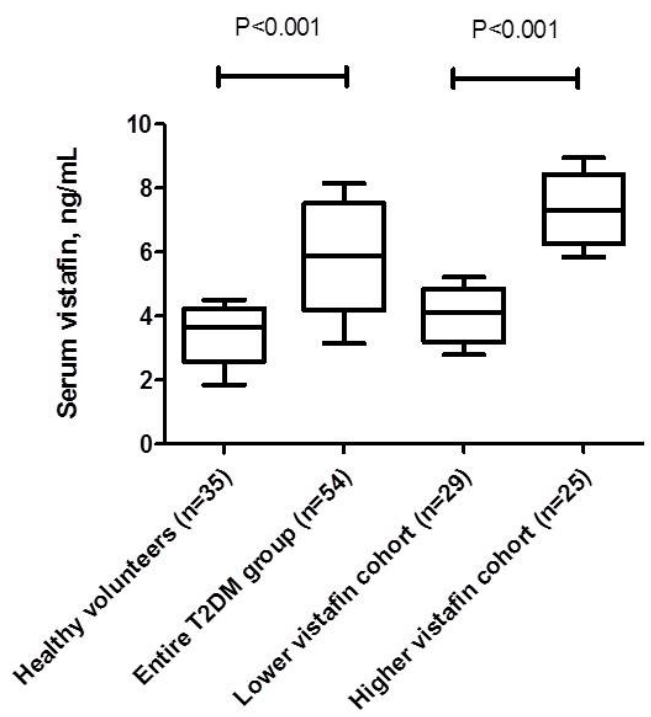

Figure3. Circulating Vistafin Level in Both T2DM Cohorts in Comparison with Healthy Volunteers

Values are reported as median and IQR, and were compared using ANOVA. 
The line within the box represents the median value; the top and bottom lines of the box reflect the 25th and 75th percentile respectively; the top and bottom vertical lines outside of the boxes represent 10th and 90th percentile respectively.

Abbreviations: ANOVA - analysis of variance, IQR - interquartile range

There were not significant differences between both cohorts of T2DM subjects with low and high vistafin levels in age, sex, hip circumference, CV risk factors (incidence of dyslipidemia, hypertension, and adherence to smoking), Framingham risk score, blood pressure, HbA1c, fasting blood glucose, insulin, HOMA-IR, creatinine, adiponectin, total cholesterol, HDL-C and LDL$\mathrm{C}$ (Table 2). Increased BMI, waist circumference, triglyceride and hs-CRP concentrations were found in T2DM patients with high vistafin level than in subjects with low vistafin level.

Table2. Demographic, Risk Factors, Blood Pressure, Circulating Biomarkers, and Number of Epcs in T2DM Patients Depending Vistafin Level

\begin{tabular}{|c|c|c|c|}
\hline Variables & Low vistafin level $(n=29)$ & High vistafin level $(n=25)$ & $\mathrm{P}$ value \\
\hline Age, years & $49.10 \pm 5.90$ & $48.30 \pm 5.70$ & 0.92 \\
\hline Males, n (\%) & $18(62.0 \%)$ & $16(64.0 \%)$ & 0.98 \\
\hline BMI, $\mathrm{kg} / \mathrm{m}^{2}$ & $24.3(16.9-28.6)$ & $29.1(25.3-32.5)$ & 0.042 \\
\hline Waist circumference, sm & $100(90-108)$ & $106(97-115)$ & 0.046 \\
\hline Hip circumference $(\mathrm{cm})$ & $106(103-110)$ & $107(102-114)$ & 0.72 \\
\hline Hypertension, n (\%) & $19(65.5 \%)$ & $17(68.0 \%)$ & 0.78 \\
\hline Dyslipidemia, n (\%) & $16(55.2 \%)$ & $17(68.0 \%)$ & 0.84 \\
\hline Adherence to smoking, n (\%) & $8(27.5 \%)$ & $7(28.0 \%)$ & 0.82 \\
\hline Framingham risk score & $8.10 \pm 2.14$ & $8.25 \pm 2.15$ & 0.80 \\
\hline Systolic BP, mm Hg & $135 \pm 5$ & $137 \pm 6$ & 0.94 \\
\hline Diastolic BP, mm Hg & $87 \pm 4$ & $88 \pm 5$ & 0.96 \\
\hline Heart rate, beats per $1 \mathrm{~min}$. & $73 \pm 5$ & $74 \pm 4$ & 0.96 \\
\hline $\mathrm{GFR}, \mathrm{mL} / \mathrm{min} / 1.73 \mathrm{~m}^{2}$ & $94.2(85.1-106.1)$ & $92.7(83.5-107.4)$ & 0.66 \\
\hline HbA1c, \% & $7.2(4.4-8.8)$ & $7.4(4.5-9.3)$ & 0.46 \\
\hline Fasting blood glucose, $\mathrm{mmol} / \mathrm{L}$ & $5.49(4.29-8.11)$ & $5.57(4.50-8.6)$ & 0.48 \\
\hline Insulin, $\mu \mathrm{U} / \mathrm{mL}$ & $15.4(12.6-15.9)$ & $15.6(12.9-17.1)$ & 0.88 \\
\hline HOMA-IR, $\mathrm{mmol} / \mathrm{L} \times \mu \mathrm{U} / \mathrm{mL}$ & $3.78(3.39-4.03)$ & $3.89(3.40-4.15)$ & 0.62 \\
\hline Creatinine, $\mu \mathrm{mol} / \mathrm{L}$ & $70.6(57.2-88.5)$ & $72.1(58.3-90.6)$ & 0.88 \\
\hline Total cholesterol, mmol/L & $5.3(4.6-5.9)$ & $5.4(4.8-5.8)$ & 0.86 \\
\hline $\mathrm{LDL}-\mathrm{C}, \mathrm{mmol} / \mathrm{L}$ & $3.78(3.20-4.15)$ & $3.82(3.30-4.20)$ & 0.72 \\
\hline HDL-C, mmol/L & $0.95(0.90-1.13)$ & $0.94(0.87-1.11)$ & 0.14 \\
\hline $\mathrm{TG}, \mathrm{mmol} / \mathrm{L}$ & $1.25(1.15-1.32)$ & $1.41(1.32-1.50)$ & 0.044 \\
\hline hs-CRP, mg / L & $7.20(3.96-9.80)$ & $9.04(5.30-11.24)$ & 0.024 \\
\hline Adiponectin, mg / L & $6.19(3.37-10.12)$ & $6.14(3.49-10.23)$ & 0.82 \\
\hline Vistafin, $\mathrm{ng} / \mathrm{mL}$ & $4.12(2.85-5.21)$ & $7.30(5.90-8.50)$ & 0.001 \\
\hline $\mathrm{CD}^{2} 5^{+} \mathrm{CD} 34^{+}$, cells $\times 10^{3} / \mu \mathrm{L}$ & $0.114(0.090-0.117)$ & $0.110(0.087-0.122)$ & 0.26 \\
\hline $\mathrm{CD}^{2} 5^{-} \mathrm{CD} 34^{+}$, cells $\times 10^{-1} / \mu \mathrm{L}$ & $0.06(0.055-0.069)$ & $0.055(0.051-0.065)$ & 0.16 \\
\hline $\mathrm{CD} 14^{+} \mathrm{CD} 309^{+}$, cells $\times 10^{-1} / \mu \mathrm{L}$ & $3.10(2.31-4.33)$ & $2.89(2.21-4.03)$ & 0.001 \\
\hline $\mathrm{CD} 14^{+} \mathrm{CD} 309^{+} \mathrm{Tie}^{2+}$, cells $\times 10^{-1} / \mu \mathrm{L}$ & $0.290(0.250-0.410)$ & $0.259(0.236-0.388)$ & 0.012 \\
\hline
\end{tabular}

Note. Data are presented as mean and \pm SE or 95\% CI; median and 25-75\% IQR. Categorical variables are expressed as numerous ( $n$ ) and percentages (\%). P-value is a comparison of mean or median variables between both cohorts (ANOVA test).

Abbreviations. $C I$ - confidence interval; IQR - inter quartile range; BMI - Body mass index, T2DM - type two diabetes mellitus, BP - blood pressure, BMI - Body mass index, GFR - glomerular filtration rate, EPCs endothelial progenitor cells; TG - triglycerides, HDL-C - high-density lipoprotein cholesterol, LDL-C - Lowdensity lipoprotein cholesterol, hs-CRP - high sensitive C reactive protein.

Similarities in numerous of $\mathrm{CD} 34^{+}$EPCs were determined in both T2DM cohorts. Contrary, $\mathrm{CD}_{1} 4^{+} \mathrm{CD} 309^{+}$and $\mathrm{CD} 14^{+} \mathrm{CD} 309^{+} \mathrm{Tie}^{2+}$ subsets of circulating EPCs were determined in higher concentration among T2DM subjects with low vistafin level versus individuals with high vistafin level ( $\mathrm{P}=0.001$ and $\mathrm{P}=0.012$ respectively). 


\section{Univariate and Multivariate Regression Analysis}

In entire T2DM group univariate regression analysis has shown statistically significant associations between serum vistafin level and BMI $(\beta=2.36,95 \% \mathrm{CI}=1.92$ to $2.96 ; \mathrm{p}=0.001)$, waist circumference $(\beta=1.98,95 \% \mathrm{CI}=1.06$ to $2.78 ; \mathrm{p}=0.001)$, hs-CRP level $(\beta=3.22,95 \% \mathrm{CI}=1.92$ to $5.16 ; \mathrm{p}=0.001)$, HOMA-IR $(\beta=8.22,95 \% \mathrm{CI}=7.12$ to $10.12 ; \mathrm{p}=0.001)$, numbers of CD14 ${ }^{+} \mathrm{CD} 309^{+}$EPCs $(\beta=-3.15,95 \% \mathrm{CI}=-5.17$ to $-1.75 ; \mathrm{p}=0.001)$, adiponectin $(\beta=-1.90,95 \% \mathrm{CI}$ $=-2.55$ to $-1.70 ; \mathrm{p}=0.001)$, numbers of $\mathrm{CD} 14^{+} \mathrm{CD} 309^{+} \mathrm{Tie}^{2+}(\beta=-2.96,95 \% \mathrm{CI}=-4.33$ to $-1.47 ; \mathrm{p}=$ $0.001)$, and age $(\beta=-1.27,95 \% \mathrm{CI}=-1.72$ to $-0.88 ; \mathrm{p}=0.001)$.

In T2DM cohort with low vistafin level there were significant associations between serum vistafin level and BMI $(\beta=3.06,95 \% \mathrm{CI}=2.10$ to $4.20 ; \mathrm{p}=0.001)$, waist circumference $(\beta=2.15,95 \% \mathrm{CI}=$ 1.44 to $2.80 ; p=0.001)$, hip circumference $(\beta=1.76,95 \% \mathrm{CI}=1.30$ to $2.25 ; \mathrm{p}=0.001)$, hs-CRP level $(\beta=2.65,95 \% \mathrm{CI}=1.88$ to $3.70 ; \mathrm{p}=0.001)$, HOMA-IR $(\beta=12.50,95 \% \mathrm{CI}=6.90$ to $19.50 ; \mathrm{p}=$ $0.001)$, adiponectin $(\beta=-2.38,95 \% \mathrm{CI}=-2.90$ to $-1.86 ; \mathrm{p}=0.001)$, age $(\beta=-2.36,95 \% \mathrm{CI}=-3.55$ to -1.13; $\mathrm{p}=0.001)$, numbers of $\mathrm{CD} 14^{+} \mathrm{CD} 309^{+} \mathrm{EPCs}(\beta=-1.03,95 \% \mathrm{CI}=-1.22$ to $-0.16 ; \mathrm{p}=0.001)$, and numbers of $\mathrm{CD} 14^{+} \mathrm{CD} 309^{+} \mathrm{Tie}^{2+}(\beta=-2.15,95 \% \mathrm{CI}=-2.67$ to $-1.62 ; \mathrm{p}=0.001)$.

In high vistafin level individuals with $\mathrm{T} 2 \mathrm{DM}$ we found significant association with serum vistafin level and BMI $(\beta=3.19,95 \% \mathrm{CI}=2.23$ to $4.34 ; \mathrm{p}=0.001)$, hs-CRP level $(\beta=4.12,95 \% \mathrm{CI}=2.15$ to $6.55 ; \mathrm{p}=0.001)$, waist circumference $(\beta=2.37,95 \% \mathrm{CI}=1.90$ to $3.05 ; \mathrm{p}=0.001)$, numbers of $\mathrm{CD}^{+} 4^{+} \mathrm{CD} 309^{+} \mathrm{EPCs}(\beta=-2.11,95 \% \mathrm{CI}=-3.15$ to $-1.21 ; \mathrm{p}=0.001)$, and numbers of $\mathrm{CD} 14^{+} \mathrm{CD} 309^{+} \mathrm{Tie}^{2+}(\beta=-2.17,95 \% \mathrm{CI}=-3.80$ to $-0.86 ; \mathrm{p}=0.001)$.

Multivariate regression analysis we found that serum vistafin level associated significantly with BMI, age, hs-CRP level, waist circumference, numbers of $\mathrm{CD} 14^{+} \mathrm{CD} 309^{+} \mathrm{EPCs}$, and numbers of CD $14^{+} \mathrm{CD} 309^{+} \mathrm{Tie}^{2+}$ EPCs (Table 3).

Table3. Association between Serum Vistafin Level and Age, BMI, Metabolic Parameters, Numbers of Epcs in Entire Group of T2DM and Separated Cohorts. The Results of Multivariable Regression Analysis

\begin{tabular}{|c|c|c|c|c|c|c|c|c|c|}
\hline \multirow[t]{2}{*}{ Variables } & \multicolumn{3}{|c|}{ Entire T2DM group $(n=54)$} & \multicolumn{3}{|c|}{$\begin{array}{l}\text { Low vistafin level cohort } \\
(\mathrm{n}=29)\end{array}$} & \multicolumn{3}{|c|}{$\begin{array}{l}\text { High vistafin level } \\
\text { cohort }(n=25)\end{array}$} \\
\hline & $\beta$ & $95 \% \mathrm{CI}$ & $\begin{array}{l}\mathrm{P} \\
\text { value }\end{array}$ & $\beta$ & $95 \% \mathrm{CI}$ & $\begin{array}{l}\mathrm{P} \\
\text { value }\end{array}$ & $\beta$ & $95 \% \mathrm{CI}$ & $\begin{array}{l}\mathrm{P} \\
\text { valu } \\
\mathrm{e}\end{array}$ \\
\hline BMI, $\mathrm{kg} / \mathrm{m}^{2}$ & 2.12 & $\begin{array}{l}1.88 \text { to } \\
2.58\end{array}$ & 0.001 & 2.15 & $\begin{array}{l}1.72 \text { to } \\
2.44\end{array}$ & 0.003 & 2.21 & $\begin{array}{l}1.65 \text { to } \\
2.70\end{array}$ & $\begin{array}{l}0.00 \\
1\end{array}$ \\
\hline $\begin{array}{l}\text { Waist circumference, } \\
\text { sm }\end{array}$ & 2.21 & $\begin{array}{l}1.59 \text { to } \\
3.31\end{array}$ & 0.001 & 2.25 & $\begin{array}{l}1.53 \text { to } \\
3.37\end{array}$ & 0.002 & 2.28 & $\begin{array}{l}1.82 \text { to } \\
3.23\end{array}$ & $\begin{array}{l}0.00 \\
1\end{array}$ \\
\hline Age, years & -1.30 & $\begin{array}{l}-1.66 \text { to } \\
-1.02\end{array}$ & 0.001 & -1.18 & $\begin{array}{l}-1.46 \text { to } \\
-0.85\end{array}$ & 0.001 & -1.25 & $\begin{array}{l}-1.51 \text { to } \\
-1.10\end{array}$ & $\begin{array}{l}0.00 \\
1\end{array}$ \\
\hline hs-CRP level, mg / L & 2.90 & $\begin{array}{l}1.94 \text { to } \\
3.96\end{array}$ & 0.001 & 2.33 & $\begin{array}{l}1.58 \text { to } \\
3.12\end{array}$ & 0.002 & 2.86 & $\begin{array}{l}1.60 \text { to } \\
4.10\end{array}$ & $\begin{array}{l}0.00 \\
1\end{array}$ \\
\hline $\begin{array}{l}\mathrm{CD}^{+} 4^{+} \mathrm{CD} 309^{+}, \text {cells } \\
\times 10^{-1} / \mu \mathrm{L}\end{array}$ & -2.56 & $\begin{array}{l}-4.20 \text { to } \\
-1.15\end{array}$ & 0.001 & -2.40 & $\begin{array}{l}-4.12 \text { to } \\
-1.08\end{array}$ & 0.001 & -2.62 & $\begin{array}{l}-4.30 \text { to } \\
-1.10\end{array}$ & $\begin{array}{l}0.00 \\
1\end{array}$ \\
\hline $\begin{array}{l}\mathrm{CD} 14^{+} \mathrm{CD} 309^{+} \mathrm{Tie}^{2+} \\
\text { cells } \times 10^{-1} / \mu \mathrm{L}\end{array}$ & -2.60 & $\begin{array}{l}-4.15 \text { to } \\
-0.33\end{array}$ & 0.001 & -2.23 & $\begin{array}{l}-3.80 \text { to } \\
-0.66\end{array}$ & 0.001 & -2.57 & $\begin{array}{l}-3.70 \text { to } \\
-0.90\end{array}$ & $\begin{array}{l}0.00 \\
1\end{array}$ \\
\hline
\end{tabular}

Abbreviations.T2DM, Type 2 Diabetes Mellitus; CI, 95\% Confidence Interval; BMI, Body Mass Index

The age- and BMI-adjusted correlation coefficients of serum visfatin and hs-CRP with other studied variables in T2DM patients are reported in Table 4. Visfatin correlates significantly with $\mathrm{CD} 14^{+} \mathrm{CD} 309^{+}$cells, $\mathrm{CD} 14^{+} \mathrm{CD} 309^{+} \mathrm{Tie}^{2+}$ cells, hs-CRP and adiponectin. Therefore, there is weak correlation between hs-CRP and numerous of $\mathrm{CD} 14^{+} \mathrm{CD} 309^{+}$and $\mathrm{CD} 14^{+} \mathrm{CD} 309^{+} \mathrm{Tie}^{2+}$ cells, adiponectin, HOMA-IR, and hip circumference.

Table4. The Age- and BMI-Adjusted Correlation Coefficients of Serum Visfatin and Hs-CRP with other Studied Variables in T2DM Patients

\begin{tabular}{|l|c|c|c|c|}
\hline \multirow{2}{*}{ Variables } & \multicolumn{2}{c|}{ Visfatin } & \multicolumn{2}{c|}{ hs-CRP } \\
\cline { 2 - 5 } & $\mathrm{R}^{2}$ & P Value & $\mathrm{R}^{2}$ & P Value \\
\hline Waist circumference, sm & 0.11 & 0.015 & 0.10 & 0.046 \\
\hline Hip circumference, sm & 0.10 & 0.012 & 0.11 & 0.044 \\
\hline
\end{tabular}


Vistafin as an Independent Predictor for Declined Numerous of Non-Classical Endothelial Progenitor Cells in Patients with Type 2 Diabetes Mellitus

\begin{tabular}{|l|c|c|c|c|}
\hline \hline hs-CRP, mg/L & 0.16 & 0.012 & 1.00 & 0.904 \\
\hline Vistafin, ng/mL & 1.00 & 0.892 & 0.16 & 0.012 \\
\hline Adiponectin, mg / L & 0.12 & 0.046 & 0.12 & 0.05 \\
\hline $\mathrm{HOMA}-\mathrm{IR}, \mathrm{mmol} / \mathrm{L} \times \mu \mathrm{U} / \mathrm{mL}$ & 0.10 & 0.044 & 0.11 & 0.042 \\
\hline $\mathrm{CD} 14^{+} \mathrm{CD} 309^{+}, \mathrm{cells} \times 10^{-1} / \mu \mathrm{L}$ & 0.17 & 0.001 & 0.12 & 0.044 \\
\hline $\mathrm{CD} 14^{+} \mathrm{CD} 309^{+} \mathrm{Tie}^{2+}$, cells $\times 10^{-1} / \mu \mathrm{L}$ & 0.18 & 0.001 & 0.13 & 0.010 \\
\hline
\end{tabular}

Abbreviations. CI, Confidence Interval; BMI, Body Mass Index; Epcs, Endothelial Progenitor Cells; Hs-CRP, High Sensitive C Reactive Protein

Logistic regression analysis was employed to predictors of circulating numbers of CD14 ${ }^{+}$EPCs (Table 5). Visfatin, hs-CRP, age and BMI were the best variables in the prediction of EPC number labeled as $\mathrm{CD} 14^{+} \mathrm{CD} 309^{+}$and $\mathrm{CD} 14^{+} \mathrm{CD} 309^{+} \mathrm{Tie}^{2+}$ cells. After adjustment of the model to age and BMI elevated visfatin level remained the best predictor for both $\mathrm{CD} 14^{+} \mathrm{CD} 309^{+}$and $\mathrm{CD} 14^{+} \mathrm{CD} 309^{+} \mathrm{Tie}^{2+} \mathrm{EPCs}(\mathrm{OR}$ 0.92, 95\% CI: 0.88-0.95; $\mathrm{P}=0.001$ and OR 0.90, 95\% CI: 0.87-0.96; $\mathrm{P}=0.001$ respectively).

Table5. Logistic Regression Analysis Demonstrating the Predictors Of EPC Numbers in T2DM Patients

\begin{tabular}{|c|c|c|c|c|}
\hline \multirow[t]{2}{*}{ Factors } & \multicolumn{2}{|c|}{$\mathrm{CD}_{14}{ }^{+} \mathrm{CD} 309^{+} \mathrm{EPCs}$} & \multicolumn{2}{|c|}{$\mathrm{CD} 14^{+} \mathrm{CD} 309^{+} \mathrm{Tie}^{2+} \mathrm{EPCs}$} \\
\hline & OR $(95 \% \mathrm{CI})$ & $\mathrm{P}$ Value & OR $(95 \% \mathrm{CI})$ & P Value \\
\hline BMI per $5.0 \mathrm{~kg} / \mathrm{m}^{2}$ & $0.95(0.92-0.98)$ & 0.012 & $0.96(0.90-0.99)$ & 0.014 \\
\hline Waist circumference per $5.5 \mathrm{sm}$ & $0.99(0.92-1.04)$ & 0.564 & $0.97(0.94-1.02)$ & 0.626 \\
\hline Hip circumference per $5.0 \mathrm{sm}$ & $0.96(0.90-1.00)$ & 0.142 & $0.96(0.91-1.01)$ & 0.448 \\
\hline Age per 5 years & $0.95(0.92-0.97)$ & 0.016 & $0.96(0.90-0.98)$ & 0.044 \\
\hline hs-CRP per $4.50 \mathrm{mg} / \mathrm{L}$ & $0.95(0.93-0.98)$ & 0.001 & $0.95(0.91-0.99)$ & 0.028 \\
\hline Vistafin per $2.5 \mathrm{ng} / \mathrm{mL}$ & $0.94(0.90-0.97)$ & 0.001 & $0.91(0.87-0.98)$ & 0.012 \\
\hline Adiponectin per $4.5 \mathrm{mg} / \mathrm{L}$ & $0.96(0.94-1.00)$ & 0.246 & $0.96(0.92-1.01)$ & 0.559 \\
\hline HOMA-IR per $0.65 \mathrm{mmol} / \mathrm{L} \times \mu \mathrm{U} / \mathrm{mL}$ & $0.97(0.92-1.02)$ & 0.489 & $0.98(0.95-1.02)$ & 0.632 \\
\hline Constant & 0.09 & 0.012 & 0.08 & 0.001 \\
\hline
\end{tabular}

Abbreviations. CI, confidence interval; BMI, Body mass index; EPCs, endothelial progenitor cells; hs-CRP, high sensitive $C$ reactive protein.

\section{DisCUSSION}

The results of the study exhibit that elevated level of vistafin in T2DM individuals predicts decreased number of non-classic angiopoetic EPCs labeled as $\mathrm{CD} 14^{+} \mathrm{CD} 309^{+}$and $\mathrm{CD} 14^{+} \mathrm{CD} 309^{+} \mathrm{Tie}^{2+}$ beyond conventional CV risk factors. We confirmed that increased BMI, waist circumference, triglyceride, age, adiponectin, and hs-CRP were the variables that appeared to be significantly associated with vistafin level in T2DM. Although both biomarkers vistafin and hs-CRP correlated well with number of $\mathrm{CD}_{14}{ }^{+} \mathrm{EPCs}$, in age- and BMI-adjusted model vistafin has exhibited the best predictive discriminant for decreased agiopoetic EPCs.

Diabetes-induced EPC dysfunction is a critical factor in microvascular and macrovascular complications [31-33]. Glucose toxicity and lipid toxicity impair endothelial nitric oxide synthase activity as well as enhances the production of reactive oxygen species, leading to endothelial dysfunction and pro-atherogenetic alterations [32, 33]. Agiopoetic EPCs were found as component of endogenous repair system that plays a pivotal role in endothelial function restore, inducing angiogenesis, and neovascularization [33].

Recent studies have demonstrated controversial findings regarding an association of vistafin level with BMI, insulin, glucose, hs-CRP, or HOMA-IR [15, 34, 35]. Because serum level of vistafin in non-CV complicated T2DM patients was higher than in diabetics with known CV disease [36], it has been suggested that vistafin might have a positive effect of repair system and prevent of microvascular and macrovascular complications [17]. Indeed, vistafin has antiapoptotic activity and has a regulatory role in inflammation, regulation of glucose homeostasis, lipid profile and immunity $[35,37,38]$. Probably, vistafin via insulin-mimicking mechanism might play a positive role in attenuating insulin resistance [39]. It can be expected that vistafin would be attenuated number and functionality of angiopoetic EPCs in T2DM without known CV disease. Unfortunately, the results of the study did not confirm the suggestion. As an explanation of the finding it has deemed that decreased number of non-classical EPCs with angiopoetic activity might be an effect of inflammatory cytokines, such as CRP. Recently it has been found a closely association between hs-CRP levels, 
oxidative stress and insulin resistance in obese individuals and patients with T2DM beyond CV disease [40, 41]. The data obtained in the study suggested a negative correlation of the hs-CRP level with numerous of EPCs and positive correlation with vistafin.

It could be questioned why there is a duality in expected effect of visfatin in T2DM? Despite elevated vistafin might positively modulate EPC differentiation via its proliferative capacity leading to increased endogenous repair ability of endothelium [42], the elevation of inflammatory cytokines, oxidative stress and insulin resistance as systemic factors could contribute in functionality and ability to differentiation of progenitor cells differenced origin including EPCs [43]. Therefore, it cannot exclude that vistafin is able to directly induce apoptotic effect and the cellular expression of inflammatory cytokines such as TNF-alpha, IL-1beta, and IL-6 in target cells [44, 45].

Nevertheless, vistafin expression is up-regulated in the persistence of inflammation that is suitable for older age, T2DM and obesity [46, 47]. Through regulation of cellular levels of NAD vistafin impacts not only cellular energetics but also NAD-dependent enzymes, such as sirtuins, which may attenuate cell survival via NF- $\kappa \mathrm{B}-d e p e n d e n t$ transcription [44, 47]. Obviously, vistafin has functional importance for EPCs and probably its cellular microenvironment as a growth factor mediating proliferation and differentiation [48]. Finally, vistafin might be found as adipokine expressed antagonistic effect on angiopoetic EPCs independently insulin resistance, glycemic control, metabolic factors, as it has been elucidated in the study [49].

Taken together, it has been suggested that vistafin could contribute to impaired diabetic reparation including impaired neovascularization and deficient EPC recruitment. Most importantly, vistafin leads to diabetes-induced EPC dysfunction in closely relation to systemic inflammation, although the underlying molecular mechanisms of vistafin might be contribute in increase of repair ability of EPCs. Further investigations are suggested on visfatin functions, signaling, and clinical significance, as well as determinants of serum visfatin level to elucidate whether this molecule can be a candidate in biomarker of T2DM progression and CV event development.

\section{Study Limitations}

This study has some limitations. The distribution of body fat and its visceral deposits were not directly assessed. Whether is interrelation between VAT, vistafin and deficiency of EPCs with angiopoetic activity is not defined and it requires further investigations. Therefore, the causal relationship between vistafin and functionality of EPCs could not be determined because we investigated number of circulating EPCs. Yet, an effect of glycemic control on predictive value of vistafin on decreased EPC count needs to be determined in future studies. Finally, authors believe that a greater cohort of patients with more incidences detected is desirable to improve the credibility of the study.

\section{Conclusion}

we found that elevated level of vistafin was an independent predictor for declined numerous of nonclassical EPCs labeled as $\mathrm{CD} 14^{+} \mathrm{CD} 309^{+}$and $\mathrm{CD} 14^{+} \mathrm{CD} 309^{+} \mathrm{Tie}^{2+}$, whereas $\mathrm{CD} 34^{+}$subsets of EPCs did not associate with vistafin level in T2DM individuals.

\section{ACKNOWLEDGMENT}

We thank all patients for their participation in the investigation, staff of the Regional Zaporozhye Hospital (Ukraine), and the doctors, nurses, and administrative staff in Regional Center of Cardiovascular Diseases (Zaporozhye, Ukraine) and City Hospital \# 6 (Zaporozhye, Ukraine), general practices, and site-managed organizations that assisted with the study.

\section{Authors' CONTRIButions}

Alexander E Berezin initiated the hypothesis and designed the study protocol, contributed to collect, analyze and interpret the data, performed statistical analysis, wrote the manuscript and approved final version of the paper. Tatyana A Samura collected, analyzed and interpreted the image scans, performed statistical analysis. Alexander A. Kremzer contributed to enroll the patients; collected and analyzed the data reviewed the source documents. Tatyana A. Berezina contributed to enroll the patients in the study and collect the data. Martovitskaya $\mathrm{YuV}$ and Elena A Gromenko contributed in blood sampling, performing of biomarker measurements with ELISA and cytofluometry, and interpreted of the obtained results. 


\section{REFERENCES}

[1] Nichols GA, Schroeder EB, Karter AJ, Gregg EW, Desai J, Lawrence JM, O'Connor PJ, Xu S, Newton KM, Raebel MA, Pathak RD, Waitzfelder B, Segal J, Lafata JE, Butler MG, Kirchner HL, Thomas A, Steiner JF; SUPREME-DM Study Group. Trends in Diabetes Incidence Among 7 Million Insured Adults, 2006-2011: The SUPREME-DM Project. Am J Epidemiol 2015; 181(1): 32-9.

[2] Sharma M, Nazareth I, Petersen I. Trends in incidence, prevalence and prescribing in type 2 diabetes mellitus between 2000 and 2013 in primary care: a retrospective cohort study. BMJ Open. 2016; 6(1): e010210.

[3] Bretón-Romero R, Feng B, Holbrook M, Farb MG, Fetterman JL, Linder EA, et al. Endothelial Dysfunction in Human Diabetes Is Mediated by Wnt5a-JNK Signaling. Arterioscler Thromb Vasc Biol. 2016 [Epub ahead of print]

[4] Prieto D, Contreras C, Sánchez A. Endothelial dysfunction, obesity and insulin resistance. Curr Vasc Pharmacol. 2014; 12(3): 412-26.

[5] Polovina MM, Potpara TS. Endothelial dysfunction in metabolic and vascular disorders. Postgrad Med. 2014; 126(2): 38-53.

[6] Kotlinowski J, Dulak J, Józkowicz A. Type 2 diabetes mellitus impairs endothelial progenitor cells functions. Postepy Biochem. 2013; 59(3): 257-66.

[7] Kuliszewski MA, Ward MR, Kowalewski JW, Smith AH, Stewart DJ, Kutryk MJ, Leong-Poi H. A direct comparison of endothelial progenitor cell dysfunction in rat metabolic syndrome and diabetes. Atherosclerosis. 2013; 226(1): 58-66.

[8] Andrade-Oliveira V, Câmara NO, Moraes-Vieira PM. Adipokines as drug targets in diabetes and underlying disturbances. J Diabetes Res. 2015; 2015: 681612.

[9] Tilg H, Moschen AR. Role of adiponectin and PBEF/visfatin as regulators of inflammation: involvement in obesity-associated diseases. Clin Sci (Lond). 2008; 114(4): 275-88.

[10] Chang YH, Chang DM, Lin KC, Shin SJ, Lee YJ. Visfatin in overweight/obesity, type 2 diabetes mellitus, insulin resistance, metabolic syndrome and cardiovascular diseases: a meta-analysis and systemic review. Diabetes Metab Res Rev. 2011; 27(6): 515-27.

[11] Esteghamati A, Alamdari A, Zandieh A, Elahi S, Khalilzadeh O, Nakhjavani M, et al. Serum visfatin is associated with type 2 diabetes mellitus independent of insulin resistance and obesity. Diabetes Res Clin Pract. 2011; 91(2): 154-8.

[12] Kolsgaard ML, Wangensteen T, Brunborg C, Joner G, Holven KB, Halvorsen B, et al. Elevated visfatin levels in overweight and obese children and adolescents with metabolic syndrome. Scand J Clin Lab Invest. 2009; 69(8):858-64.

[13] Krzystek-Korpacka M, Patryn E, Bednarz-Misa I, Hotowy K, Noczynska A. Visfatin in juvenile obesity - the effect of obesity intervention and sex. Eur J Clin Invest. 2011; 41(12):1284-91.

[14] Fukuhara A, Matsuda M, Nishizawa M, Segawa K, Tanaka M, Kishimoto K, et al. Visfatin: a protein secreted by visceral fat that mimics the effects of insulin. Science. 2005; 307(5708): 42630.

[15] Alghasham AA, Barakat YA. Serum visfatin and its relation to insulin resistance and inflammation in type 2 diabetic patients with and without macroangiopathy. Saudi Med. J. 2008; 29: $185-192$

[16] Xie H, Tang SY, Luo XH, Huang J, Cui RR, Yuan LQ, et al. Insulin-like effects of visfatin on human osteoblasts. Calcif Tissue Int. 2007; 80(3):201-10.

[17] Skoczylas A. The role of visfatin in the pathophysiology of human. Wiad Lek. 2009; 62(3):1906.

[18] Bettencourt N, Oliveira S, Toschke AM, Rocha J, Leite D, Carvalho M, Xará S, Schuster A, Chiribiri A, Leite-Moreira A, Nagel E, Alves H, Gama V. Predictors of circulating endothelial progenitor cell levels in patients without known coronary artery disease referred for multidetector computed tomography coronary angiography. Rev Port Cardiol. 2011; 30(10):75360. 
[19] Humpert PM, Eichler H, Lammert A, Hammes HP, Nawroth PP, Bierhaus A. Adult vascular progenitor cells and tissue regeneration in metabolic syndrome. Vasa. 2005; 34(2):73-8, 80.

[20] Cubbon RM, Kahn MB, Wheatcroft SB. Effects of insulin resistance on endothelial progenitor cells and vascular repair. Clin Sci (Lond). 2009; 117(5):173-90.

[21] Berezin AE, Kremzer AA. Analysis of Various Subsets of Circulating Mononuclear Cells in Asymptomatic Coronary Artery Disease. J. Clin. Med. 2013; 2: 32-44.

[22] Seeger FH, Chen L, Spyridopoulos I, Altschmied J, Aicher A, Haendeler J. Downregulation of ETS rescues diabetes-induced reduction of endothelial progenitor cells. PLoS One. 2009; 4(2): e4529.

[23] Berezin AE, Kremzer AA. Signature of circulating endothelial-derived progenitor cells in patients with metabolic syndrome and diabetes mellitus. Biological Markers and Guided Therapy. 2015; 2 (1): 113-135

[24] António N, Fernandes R, Soares A, Soares F, Lopes A, Carvalheiro T, et al. Reduced levels of circulating endothelial progenitor cells in acute myocardial infarction patients with diabetes or pre-diabetes: accompanying the glycemic continuum. Cardiovasc Diabetol. 2014; 13: 101.

[25] American Diabetes Association. Standards of medical care in diabetes-2015 abridged for primary care providers. Clin Diabetes. 2015; 33(2):97-111.

[26] Bluemke DA, Achenbach S, Budoff M, Gerber TC, Gersh B, Hillis LD, et al. Noninvasive coronary artery imaging: magnetic resonance angiography and multidetector computed tomography angiography: a scientific statement from the American Heart Association Committee on Cardiovascular Imaging and Intervention of the Council on Cardiovascular Radiology and Intervention, and the Councils on Clinical Cardiology and Cardiovascular Disease in the Young. Circulation. 2008; 118: 586-606

[27] Preiss D, Kristensen SL. The New Pooled Cohort Equations Risk Calculator. Can J Cardiol. 2015; 31(5):613-619.

[28] Levey AS, Stevens LA, Schmid CH, Zhang YL, Castro AF 3rd, Feldman HI, et al; for the CKDEPI (Chronic Kidney Disease Epidemiology Collaboration). A New Equation to Estimate Glomerular Filtration Rate. Ann Intern Med. 2009; 150(9): 604-12.

[29] Matthews DR, Hosker JP, Rudenski AS, Naylor BA, Treacher DF, Turner RC. Homeostasis model assessment: insulin resistance and beta-cell function from fasting plasma glucose and insulin concentrations in man. Diabetologia. 1985; 28: 412-419.

[30] Tung JW, Parks DR, Moore WA, Herzenberg LA, Herzenberg LA. New approaches to fluorescence compensation and visualization of FACS data. Clin. Immunol. 2004, 110, 277-83.

[31] Tousoulis D, Papageorgiou N, Androulakis E, Siasos G, Latsios G, Tentolouris K. et al. Diabetes mellitus-associated vascular impairment: novel circulating biomarkers and therapeutic approaches. J Am Coll Cardiol. 2013; 62(8): 667-676.

[32] António N, Fernandes R, Soares A, Soares F, Lopes A, Carvalheiro T, et al. Reduced levels of circulating endothelial progenitor cells in acute myocardial infarction patients with diabetes or pre-diabetes: accompanying the glycemic continuum. Cardiovasc Diabetol. 2014; 13:101.

[33] Alev C., Ii M., Asahara T. Endothelial progenitor cells: a novel tool for the therapy of ischemic diseases. Antioxidants and Redox Signaling. 2011; 15(4): 949-965.

[34] Garten A, Petzold S, Schuster S, Körner A, Kratzsch J, Kiess W. Nampt and its potential role in inflammation and type 2 diabetes. Handb Exp Pharmacol. 2011; (203):147-64.

[35] Wang P, van Greevenbroek MM, Bouwman FG, Brouwers MC, van der Kallen CJ, Smit E, et al. The circulating PBEF/NAMPT/visfatin level is associated with a beneficial blood lipid profile. Pflugers Arch. 2007; 454(6): 971-6.

[36] Kadoglou NP, Sailer N, Moumtzouoglou A, Kapelouzou A, Tsanikidis H, Vitta I, et al. Visfatin (nampt) and ghrelin as novel markers of carotid atherosclerosis in patients with type 2 diabetes. Exp Clin Endocrinol Diabetes. 2010; 118(2):75-80.

[37] Sonoli SS, Shivprasad S, Prasad CV, Patil AB, Desai PB, Somannavar MS. Visfatin - a review. Eur Rev Med Pharmacol Sci. 2011; 15(1): 9-14.

[38] Chang YC, Chang TJ, Lee WJ, Chuang LM. The relationship of visfatin/pre-B-cell colonyenhancing factor/nicotinamide phosphoribosyltransferase in adipose tissue with inflammation, insulin resistance, and plasma lipids. Metabolism. 2010; 59(1): 93-9. 
[39] Sun Q, Li L, Li R, Yang M, Liu H, Nowicki MJ, et al. Overexpression of visfatin/PBEF/Nampt alters whole-body insulin sensitivity and lipid profile in rats. Ann Med. 2009; 41(4):311-20.

[40] Tangvarasittichai S, Pongthaisong S, Tangvarasittichai O. Tumor Necrosis Factor-A, Interleukin6, C-Reactive Protein Levels and Insulin Resistance Associated with Type 2 Diabetes in Abdominal Obesity Women. Indian J Clin Biochem. 2016; 31(1):68-74.

[41] Turker Y, Baltaci D, Turker Y, Ozturk S, Sonmez CI, Deler MH, et al. Investigation of relationship of visceral body fat and inflammatory markers with metabolic syndrome and its components among apparently healthy individuals. Int J Clin Exp Med. 2015; 8(8): 13067-77.

[42] Moschen AR, Gerner RR, Tilg H. Pre-B cell colony enhancing factor/NAMPT/visfatin in inflammation and obesity-related disorders. Curr Pharm Des. 2010; 16(17): 1913-20.

[43] Berezin AE, Kremzer AA, Cammarota G, Zulli A, Petrovic D, Martell-Claros N, et al. Circulating endothelial-derived apoptotic microparticles and insulin resistance in non-diabetic patients with chronic heart failure. Clin Chem Lab Med. 2015 doi: 10.1515/cclm-2015-0605. [Epub ahead of print]

[44] Luk T, Malam Z, Marshall JC. Pre-B cell colony-enhancing factor (PBEF)/visfatin: a novel mediator of innate immunity. J Leukoc Biol. 2008; 83(4):804-16.

[45] Moreschi I, Bruzzone S, Nicholas RA, Fruscione F, Sturla L, Benvenuto F, et al. Extracellular $\mathrm{NAD}+$ is an agonist of the human P2Y11 purinergic receptor in human granulocytes J. Biol. Chem. 2006; 281,31419-31429

[46] Sethi J K, Vidal-Puig A. Visfatin: the missing link between intra-abdominal obesity and diabetes? Trends in Molecular Medicine. 2005; 11(8), 344-347.

[47] Yeung F, Hoberg J E, Ramsey C S, Keller MD, Jones DR, Frye RA, et al. Modulation of NF-кBdependent transcription and cell survival by the SIRT1 deacetylase EMBO J. 2004; 23,23692380

[48] Yang H, Lavu S, Sinclair DA. Nampt/PBEF/visfatin: a regulator of mammalian health and longevity? Exp. Gerontol. 2006; 41,718-726.

[49] Berezin AE. Biological markers of cardiovascualr diseases. Part 3. Diagnostic and prognostic value of biological markers in stratification of patients with cardiometabolic risk. Lambert Academic Publishing GmbH, Moscow, 2015. - 300 p. 